\title{
Effects of Aquatic Plants on Nutrient Concentration in Water and Growth Performance of Fantail Goldfish in an Aquaculture System
}

\author{
Mohd Naqib Azfar Mohd Roslan, Abentin Estim *(D), Balu Alagar Venmathi Maran (D) and Saleem Mustafa
}

Borneo Marine Research Institute, Universiti Malaysia Sabah, Jalan UMS, Kota Kinabalu 88400, Sabah, Malaysia; mohdnaqibazfar@gmail.com (M.N.A.M.R.); bavmaran@ums.edu.my (B.A.V.M.); saleem@ums.edu.my (S.M.)

* Correspondence: bentin@ums.edu.my; Tel.: +60-88-320000 (ext. 2592); Fax: +60-88-320261

Citation: Roslan, M.N.A.M.; Estim, A.; Venmathi Maran, B.A.; Mustafa, S. Effects of Aquatic Plants on Nutrient Concentration in Water and Growth Performance of Fantail Goldfish in an Aquaculture System. Sustainability 2021, 13, 11236. https://doi.org/ $10.3390 /$ su132011236

Academic Editors: Takeshi Miura and Marc A. Rosen

Received: 8 July 2021

Accepted: 4 October 2021

Published: 12 October 2021

Publisher's Note: MDPI stays neutral with regard to jurisdictional claims in published maps and institutional affiliations.

Copyright: (c) 2021 by the authors. Licensee MDPI, Basel, Switzerland. This article is an open access article distributed under the terms and conditions of the Creative Commons Attribution (CC BY) license (https:/ / creativecommons.org/licenses/by/ $4.0 /)$.

\begin{abstract}
The effects of two aquatic plants, duckweed (Lemna sp.) and azolla (Azolla sp.), on the growth performance of fantail goldfish (Carassius auratus) and dissolved nutrient concentrations were studied. The experiments were carried out in triplicate sets over a period of seven weeks. Eight specimens of fantail goldfish (length $=5.16 \pm 0.06 \mathrm{~cm}$; body weight $=2.30 \pm 0.06 \mathrm{~g}$ ) were released into each of the aquariums containing $40 \mathrm{~L}$ of water. Submerged sponge filters were used as the substrate (bed) for the nitrifying bacteria to facilitate nitrification. The fish were provided feed at the rate of $2 \%$ of their body weight twice daily. In situ and ex situ water parameters (temperature, dissolved oxygen, $\mathrm{pH}$, total suspended solids, ammonia, nitrite, nitrate, and phosphate), body weight and length of the Fantail goldfish, and wet weight of aquatic plants were measured weekly. The results showed no significant differences $(p>0.05)$ in any of the three aquariums in water temperature, $\mathrm{pH}$, and dissolved oxygen. Survival of the fish was $100 \%$. The highest food conversion ratio and specific growth rate were observed in the aquarium stocked with duckweed, followed by the aquarium with azolla and the control set $(p<0.05)$. The concentrations of nutrients (ammonia and nitrate) were recorded lowest $(p<0.05)$ in the aquarium with azolla, followed by duckweed and the control. The results suggested that aquatic plants were effective in absorbing nutrients and can serve as biofilters to create better conditions for the growth of the fantail goldfish.
\end{abstract}

Keywords: integrated culture; ornamental fish; weed plants; nutrient profiles; dynamic equilibrium; species compatibility

\section{Introduction}

Ornamental fish culture is a growing industry and is considered a profitable enterprise. Some fish species are often referred to as 'living jewels,' referring to their attractive colouration and fascinating behaviour [1]. The important qualities of ornamental fish are colouration and patterns, acceptance of artificial feed, resilience to captive conditions, and compatibility with members of the same or different species [1,2]. Many of the ornamental fish species possess these attributes and are of small size that can be easily accommodated in the aquarium [3]. In Malaysia, ornamental fish keeping is a popular hobby. Furthermore, Malaysia exports more than 200 ornamental fish species to cater to the overseas demand [4]. The ornamental fish trade creates jobs and income and contribute to economy [1].

Carassius auratus (Linnaeus, 1758), known as fantail goldfish, is among the most popular ornamental fish belonging to the family Cyprinidae and subfamily Cyprininae [2]. Historically, it is one of the earliest fishes to be domesticated for aquariums. Its mouth is small and terminal, without barbels, and the fish does not possess a tail spot and has fewer than 31 scales along the lateral line. It is a scaly, high-bodied, and laterally compressed fish; the dorsal fin is long with a slightly serrated third spine. Fantail goldfish resembles the crucian carp, Carassius carassius (Linneaus, 1758), but it is more elongated and has a slightly concave dorsal fin and larger scales [5]. Typically, goldfish can hybridize with some other Carassius carp species. It can also interbreed with Koi and common carp to produce sterile 
hybrids. The domestication process of goldfish strains has been documented in many different countries [6]. Goldfish may grow to $45 \mathrm{~cm}$ total length (TL) and $3 \mathrm{~kg}$ body weight; however, their average size observed is $20 \mathrm{~cm} \mathrm{TL}$, and they weigh around 100-300 g. The life span of the fish is typically six to seven years, but it can be as long as 30 years. Typical habitat includes weedy ponds, shallow lakes, and slow-flowing rivers, especially those with submerged aquatic vegetation [5]. It is an opportunistic feeder and accepts various types of foods that can fit its mouth size [2,3]. Fantail goldfish possess high appetite, resulting in large quantities of metabolic waste in the water through faeces and gills [7]. If the waste is not efficiently handled, water quality impairment creates insanitation and mortality of the fish. The nitrogenous waste of significant concern is ammonia, which is highly toxic. Even in small amounts, it causes stress to the fish and makes it susceptible to bacterial infections and other health problems $[2,8]$.

Usually, aquariums are provided with filtration systems to maintain water quality. It is vital to select an appropriate filtration system for the aquarium according to selected species and their maintenance requirements [9]. Biological filtration can be very effective in the removal of excess ammonia in the aquarium water. Ammonia and nitrite concentrations are reduced by nitrifying bacteria that colonize the suitable substrate to carry out the biological filtration [10]. It is the process of oxidation of the waste products in which ammonia $\left(\mathrm{NH}_{3}\right)$ is oxidized to nitrite $\left(\mathrm{NO}_{2}{ }^{-}\right)$, which is converted to nitrate $\left(\mathrm{NO}_{3}{ }^{-}\right)$that is relatively much less toxic compared to $\mathrm{NH}_{3}$ and $\mathrm{NO}_{2}{ }^{-}$. Conversion of $\mathrm{NH}_{3}$ to $\mathrm{NO}_{2}{ }^{-}$is carried out by Nitrosomonas sp. bacteria. While the other group of bacteria, called Nitrobacter sp., transforms $\mathrm{NO}_{2}{ }^{-}$to $\mathrm{NO}_{3}{ }^{-}$. Although $\mathrm{NO}_{3}{ }^{-}$is not very toxic to fish, its accumulation in large concentrations for extended periods can become a problem $[8,10]$. This problem can be addressed by stocking selected species of plants for uptake of $\mathrm{NO}_{3}$ as a nutrient to gain biomass. In this manner, the water quality problem is controlled to sustain the aquarium operations.

Generally, plants are known for the uptake of nitrate; however, all the species of plants do not function properly and survive under aquarium conditions. In this study, two types of aquatic plants, duckweed (Lemna sp.) and azolla (Azolla sp.), were selected for stocking in the aquarium with the fantail goldfish. Both plants have small leaves that float on the water surface, and fish are often seen biting off pieces of the leaves, suggesting that these plants can also be a source of nourishment. Moreover, both these plants can reproduce by sexual as well as vegetative (asexual) methods for self-renewal [10]. Kabir et al. [11] have suggested duckweed as a good source of vitamins and minerals in addition to a small proportion of protein. Duckweed and azolla grow in stagnant and sewage-fed water bodies and are considered obnoxious due to their tendency to overgrow, choke drains, and hamper fishing and clearance operations. These plants have no market value or possess very low price $[10,11]$.

Fantail goldfish is a popular species in Malaysia [4]. The market price is RM (Malaysian Ringgit) 1.05 (=USD 0.25) for specimens measuring 55-60 cm. The fish has a double anal and caudal fin. The anal and caudal fins are split into two corresponding halves. Although typically considered a hardy species, goldfish can be susceptible to extended exposure to low water temperatures. It is exceptionally eurythermal, which can survive for limited durations at temperatures between $0{ }^{\circ} \mathrm{C}$ and $41^{\circ} \mathrm{C}$ and at temperatures close to $44^{\circ} \mathrm{C}$ [12] but only for a short period of exposure. This ability to tolerate such a wide range of temperatures has contributed to goldfish's wide zoogeographic distribution. While in captivity, the fantail goldfish are maintained by not placing them under direct sunlight because the temperature can rise when the volume is small beyond the tolerance level of the fish. Fantail goldfish eat and produce considerable amounts of waste. In the aquarium, wastes can impair water quality if not efficiently treated $[4,7,8]$.

Lemna sp. is the largest genus in the family Lemnaceae [13]. Lemna disperna and L. gibba are related to progenitor-derived species, however, the latter species is different from L. disperna. Lemna spp. are of medium size, around 6 to $8 \mathrm{~mm}$ [14]. The newly formed fronds remain attached to the parent frond during the initial stage of growth, and the plant 
appears to be made up of several fronds. Lemna sp. generally grows to a size of $0.5-1.0 \mathrm{~cm}$ and is suitable for fish feed. It has the ability of improving water quality by absorbing waste from water [14,15]. It is also suitable for small fish that bite off pieces for food [9]. Duckweed is easy to culture because it can reproduce through asexual reproduction and vegetative propagation, and it is adapted to a large variety of geographical and climatic areas [13-15].

The other aquatic plant is azolla, also known as mosquito fern. This common name has been given due to the weed's quality to control mosquitoes that attempt to lay eggs in the water [16]. Azolla measures $0.5-3 \mathrm{~cm}$ [17]. The advantages of using these aquatic plants include nutrient uptake and water quality enhancement [18] in addition to being a good source of dietary nutrients. Azolla possesses small size and also floats on the water surface, which makes it easy for fish to consume its soft tissues [19]. Azolla is amenable to culture and grows by sexual and asexual reproduction. It is a source of essential amino acids (EAA) for meeting the nutritional requirements of the animals [17-19]. It is rich in lysine and contains more crude protein (from 19 to 30\%) than most green forage plants and aquatic macrophytes. Recently, Liu et al. [20] have reported using Azolla sp. in an Ecological Controlled Survival System (CELSS) its photosynthetic ability to release oxygen. The potential for growing Azolla sp. is limited by climatic factors, the availability of water and inoculum, pests, and the need for phosphorus management [17]. Water volumes are essential for the growth and reproduction of azolla. It is vulnerable to water shortages. Although azolla may grow on wet mud surfaces, it prefers floating conditions [20]. In this study, we investigated the effects of duckweed and azolla on the concentrations of nutrients and growth performance of fantail goldfish.

Fantail goldfish possess high appetite and actively release products of catabolism in the water through their faeces as well as gills, causing water quality problems that require frequent cleaning $[7,10]$. Any delay in this process is reflected in water becoming cloudy and increasing vulnerability of the fish to health problems. Biological filtration helps in dealing with this problem by neutralizing the toxic waste products into a form that is easily utilized by the plants for nourishment [8-10].

\section{Materials and Methods}

\subsection{Experimental Setup}

The trial was conducted at the Integrated Multi-Trophic Aquaculture (IMTA)-Aquaponic Research Area of Borneo Marine Research Institute (BMRI), Universiti Malaysia Sabah, Malaysia. Nine aquariums, each of $0.5 \mathrm{~m}$ length $\times 2.5 \mathrm{~m}$ width $\times 0.3 \mathrm{~m}$ height, were set up. Triplicate tanks were prepared for each treatment (two aquatic plants-duckweed and azolla; and control without aquatic plants). The arrangement of aquariums was randomized and placed on an even surface. Each aquarium was filled with $40 \mathrm{~L}$ of treated water with an aeration tube and air stone to ensure adequate oxygen and water mixing in the aquarium (Figure 1).

A sponge filter of the size that could fill a $1.5 \mathrm{~L}$ plastic bottle was placed into each aquarium. The sponge filter used aeration to lift the water (Figure 2). The sponge pieces of an average size of $48 \mathrm{~cm}^{3}$, numbering 6 to 8 per bottle, were used as a bed for nitrifying bacteria. They were left for one week for bacteria colonization. The filtration apparatus comprised a submerging sponge with a $1.5 \mathrm{~L}$ plastic bottle, PVC pipe and elbow with a diameter of $2.5 \mathrm{~cm}$, sponge, stone, and aeration tube (Figure 2). Eight specimens of fantail goldfish were released in each aquarium. The weight and length of fantail goldfish in this experiment were $2.30 \pm 0.06 \mathrm{~g}$ and $5.16 \pm 0.06 \mathrm{~cm}$, respectively. This is a widely used size of aquarium among the hobbyists. 


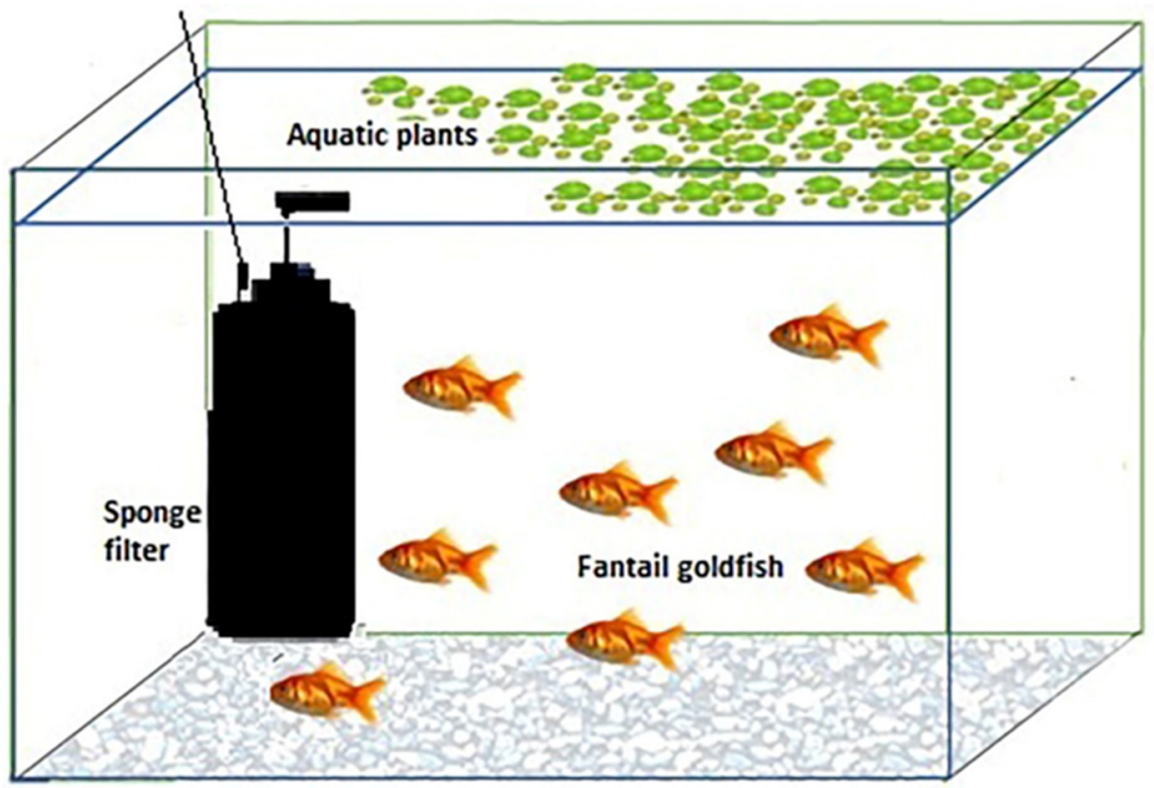

(a)

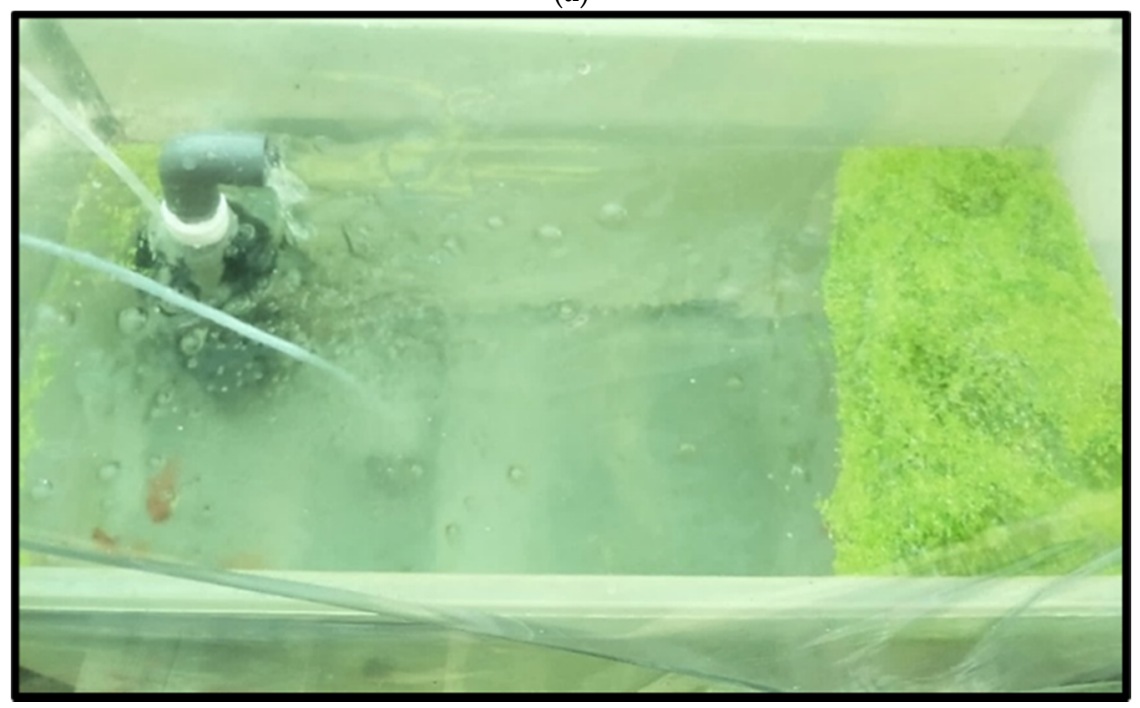

(b)

Figure 1. (a) Design of the 40-L aquarium (size $0.5 \mathrm{~m}$ length $\times 2.5 \mathrm{~m}$ width $\times 0.3 \mathrm{~m}$ high) used in the study with fantail goldfish and aquatic plants (duckweed and azolla) with a sponge filter. (b) Top view of the aquarium with aquatic plants on the surface.

Two aquatic plants, duckweed (Lemna sp.) and azolla (Azolla sp.), and a control set were used in the experiment with triplicate aquariums. Duckweed and azolla were obtained from tilapia culture at the BMRI and placed into each of the triplicate treatment aquariums. Plant biomass was about $25.0 \pm 0.5 \mathrm{~g}$ in each aquarium. The fantail goldfish was nourished by the standard commercially available feed (Aquadine Takara SakanaII Floating Pellets). It contained $27.0 \%$ crude protein, $2.0 \%$ crude fat, $5.0 \%$ crude fibre, and $9.0 \%$ crude ash. The fish were fed $2.0 \%$ of the body weight twice daily. An equal amount of feed was provided in the morning and evening feeding times as suggested by Rehman et al. [21].

\subsection{Measurement of Fantail Goldfish and Aquatic Plants}

Length and weight of the fantail goldfish were measured weekly for seven weeks. A digital balance and ruler were used for recording the body weight and length of the fish. Fish weight was measured in a pre-weighed glass beaker containing $500 \mathrm{~mL}$ of water 
to minimize the handling stress on fish. Gain in weight caused by release of the fish provided the bodyweight estimate. Aquariums were monitored thrice daily throughout the experiment in order to determine the survival. At the end of the experiment, the data were processed for calculating the percentage of survival and growth.

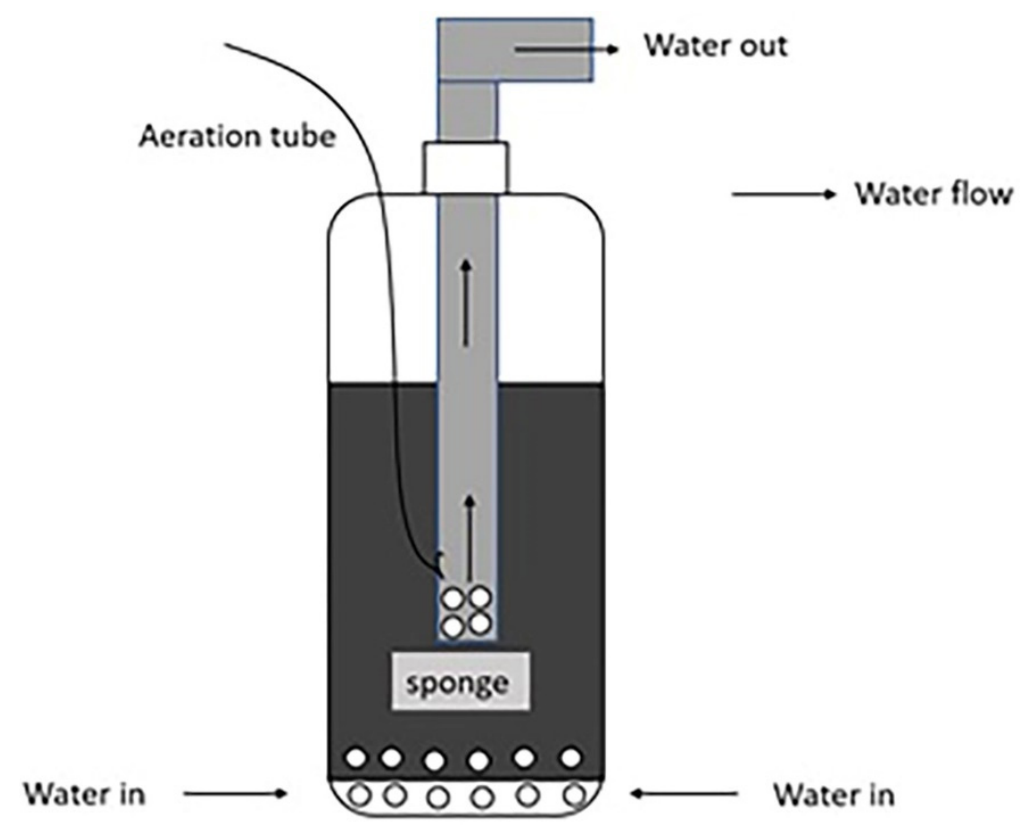

Figure 2. Sponge filters in a plastic bottle size used as a bacteria bed.

Measurements of aquatic plants were conducted in order to know the amount of azolla and duckweed eaten by the goldfish. The wet weight of aquatic plants was recorded using the electronic balance. The amount of azolla and duckweed initially placed was $25.0 \pm 0.5 \mathrm{~g}$ in each aquarium. The plants' weight was measured weekly to ensure that aquatic biomass in each aquarium was constant $(25.0 \pm 0.5 \mathrm{~g})$. Dry weight was used to calculate feed intake and feed conversion ratio [22]. Growth of azolla and duckweed was determined by using quadrat sampling. The area covered by aquatic plants was calculated by using the net $0.5 \mathrm{~m} \times 0.25 \mathrm{~m}$ with a size $5 \mathrm{~cm} \times 5 \mathrm{~cm}$. The following formula was used to calculate the density. Figure 3 shows the quadrat sampling of duckweed and azolla on the water surface of the aquariums.

\section{$0.5 \mathrm{~m}$}

$0.25 \mathrm{~m}$

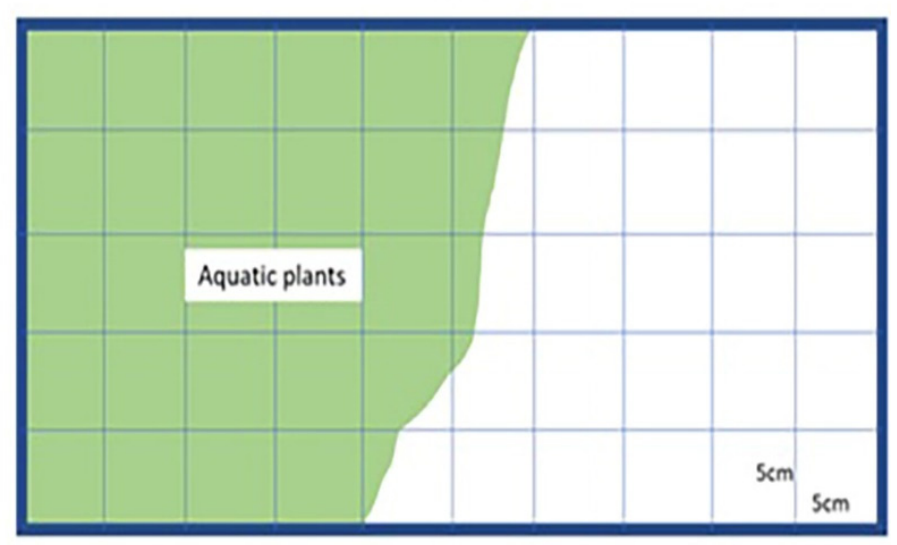

Figure 3. Upper view of the quadrat sampling cover with aquatic plants (duckweed and Azolla) on the water surface of each aquarium. 
The following formulas have been used to estimate various parameters [21,22], such as the following:

- $\quad$ Survival Rate $(\mathrm{SR} \%)=($ Number of fish at the end of the experiment/Number of fish at the beginning of the experiment $) \times 100)$;

- Weight gained $(W G \%)=[($ Final weight, g-Initial weight, g) $/$ Initial weight, g] $\times 100$;

- $\quad$ Specific growth rates $(\mathrm{SGR} \%)=[($ Final weight, g-Initial weight, g) $/$ No. of day $] \times 100$;

- $\quad$ Feed Conversion Ratio $($ FCR\% $)=[$ Feed fed $(\mathrm{g}) /$ Weight gained $(\mathrm{g})] \times 100$.

\subsection{Water Analyses}

Water parameters such as temperature, $\mathrm{pH}$, and dissolved oxygen (DO) were measured by using a multi-sensor YSI instrument on a weekly basis. Analysis of nutrients and Total Suspended Solids (TSS) was carried out at the interval of seven days. Water samples were collected from each of the aquariums using a $250 \mathrm{~mL}$ polyethylene bottle immersed in the water surface of each aquarium. Then, all water samples were brought to the Chemical Laboratory of BMRI for further analyses. The water samples were then filtered using a filtration apparatus (membrane filter with diameter $47 \mathrm{~mm}$ and pore size $0.45 \mu \mathrm{m}$, funnel and receiver $500 \mathrm{~mL}$ from Nalgene ${ }^{\mathrm{TM}}$, and electrical pump) to calculate the TSS. TSS was calculated gravimetrically by filtering the water samples and weighing the Whatman filter paper's residue. The filtered $250 \mathrm{~mL}$ samples were then used for nutrients analyses using colorimetric methods as suggested by Wetzel and Likens [23].

\subsection{Statistical Analysis}

All the quantitative data were analyzed using SPSS software version 27.0 and expressed as mean \pm standard deviation (SD). Water quality variables such as $\mathrm{DO}, \mathrm{pH}$, temperature, TSS, $\mathrm{NH}_{3}-\mathrm{N}, \mathrm{NO}_{2}-\mathrm{N}, \mathrm{NO}_{3}-\mathrm{N}$, and $\mathrm{PO}_{4}-\mathrm{P}$ were analyzed using one-way ANOVA for comparison. Measurement of growth performance of fantail goldfish included initial and final weight, initial and final length, weight and length gain, SGR, survival, feed intake, and FCR. Duncan tests were used to compare the mean values of the three different treatments.

\section{Results and Discussion}

\subsection{In Situ Water Quality}

Table 1 presents the mean $(+\mathrm{SD})$ of $\mathrm{DO}, \mathrm{pH}$, and temperature in the three different experimental sets. Statistical analyses showed that $\mathrm{DO}, \mathrm{pH}$, and temperature were not significantly different $(p>0.05)$ between the three sets. DO ranged from $6.95 \pm 1.00 \mathrm{mg} / \mathrm{L}$ to $7.39 \pm 2.03 \mathrm{mg} / \mathrm{L}, \mathrm{pH}$ varied from $7.81 \pm 0.39$ to $7.89 \pm 0.46$, and temperature fluctuated in the range of $32.21 \pm 1.63^{\circ} \mathrm{C}$ to $32.42 \pm 1.7^{\circ} \mathrm{C}$.

Table 1. TSS, NH3-N, NO2-N, NO3-N, and PO4-P in three different treatments sets.

\begin{tabular}{ccccc}
\hline Parameter & \multicolumn{3}{c}{ Treatment } \\
\hline tREA & $\mathbf{n}$ & Azolla & Duckweed & Control \\
\hline $\mathrm{DO}(\mathrm{mg} / \mathrm{L})$ & 24 & $6.95 \pm 1.00$ & $7.39 \pm 2.03$ & $7.20 \pm 1.28$ \\
pH & 24 & $7.80 \pm 0.41$ & $7.81 \pm 0.39$ & $7.89 \pm 0.46$ \\
Temperature $\left({ }^{\circ} \mathrm{C}\right)$ & 24 & $32.03 \pm 1.68$ & $32.21 \pm 1.63$ & $32.42 \pm 1.71$ \\
TSS $(\mathrm{mg} / \mathrm{L})$ & 24 & $23.022 \pm 8.900^{\mathrm{a}}$ & $26.268 \pm 13.414^{\mathrm{a}}$ & $41.026 \pm 37.099^{\mathrm{b}}$ \\
$\mathrm{NH}_{3}-\mathrm{N}(\mathrm{mg} / \mathrm{L})$ & 24 & $0.055 \pm 0.037^{\mathrm{a}}$ & $0.093 \pm 0.067^{\mathrm{b}}$ & $0.098 \pm 0.075^{\mathrm{b}}$ \\
$\mathrm{NO}_{2}-\mathrm{N}(\mathrm{mg} / \mathrm{L})$ & 24 & $0.028 \pm 0.060^{\mathrm{a}}$ & $0.009 \pm 0.006^{\mathrm{a}}$ & $0.012 \pm 0.009^{\mathrm{a}}$ \\
$\mathrm{NH}_{3}-\mathrm{N}(\mathrm{mg} / \mathrm{L})$ & 24 & $0.822 \pm 0.823^{\mathrm{a}}$ & $0.924 \pm 0.918^{\mathrm{a}}$ & $1.653 \pm 1.648^{\mathrm{b}}$ \\
$\mathrm{PO}_{4}-\mathrm{P}(\mathrm{mg} / \mathrm{L})$ & 24 & $0.913 \pm 0.815^{\mathrm{ab}}$ & $0.672 \pm 0.817^{\mathrm{a}}$ & $1.401 \pm 1.488^{\mathrm{b}}$ \\
\hline
\end{tabular}

Note: Values are expressed as mean + standard deviation, $\mathrm{n}=24$. Different superscript letters ${ }^{\mathrm{a}, \mathrm{b}}$ within a column indicates significant differences between treatments measured at $p<0.05$. 
DO is the primary water quality consideration in any aquaculture or rearing system [24] because fish consume oxygen from water by passive diffusion through gills. Colt and Tamasso [25] reported that an adequate DO concentration in the water is required to facilitate diffusion with respect to a concentration gradient from the water into the fish blood. In this study, DO was recorded in the normal range (Table 1). There is a general agreement on the lower limit of DO to be around $4.0 \mathrm{mg} / \mathrm{L}$ [24]. Fish cannot convert the energy efficiently into usable form if DO concentration is lower than the required level, resulting in impaired swimming ability, reduced growth rate, and lower feed efficiency [26]. The immediate response of fish to decreased DO concentration manifests in increased opercular ventilation rate and gasping [24,26].

Optimal temperatures for growth and spawning have been examined for many species that are important in ornamental trade. The ideal temperature for fantail goldfish in the aquarium is $18-26{ }^{\circ} \mathrm{C}$ [5]. Nico [27] reported that goldfish could survive even at temperatures above $30^{\circ} \mathrm{C}$, although not for a long duration of exposure. However, in this study, the water temperature in the three different treatments ranged from $32.21 \pm 1.63{ }^{\circ} \mathrm{C}$ to $32.42 \pm 1.71{ }^{\circ} \mathrm{C}$, and all fantail goldfish survived the experimental period. Higher temperature is known to reduce the amount of oxygen in the water, and this requires decreasing stocking density [28]. The solubility of oxygen in water depends on temperature, total dissolved solids, and the partial pressure of oxygen in the atmosphere. Boyd and Tucker [24] have discussed the oxygen solubility and temperature relation in the water at $760 \mathrm{~mm} \mathrm{Hg}$ pressure. Skillicorn et al. [29] have highlighted that the duckweed is adapted to a wide variety of geographic and climatic zones and is distributed worldwide, except in areas where the temperature falls below $0{ }^{\circ} \mathrm{C}$. Most of these species are found in the moderate climate of tropical and temperate zones. Although they can survive in extreme temperatures, moderate, warm, and sunny conditions are better for its growth [29]. Landolt [14] explained that the fish exhibits faster growth in the tropics due to these factors. Four species of azolla have originated from temperate, sub-tropical, and tropical regions of North and South America [30], and their rearing success is limited by climatic factors, water and inoculum availability, pest incidence, phosphorus requirements, and the need for labor-intensive management [17]. Water is critical to the growth and multiplication of Azolla sp. Although Azolla sp. may grow on wet mud surfaces or wet pit litters, it prefers growing in a free-floating state [17].

The management of $\mathrm{pH}$ was also necessary for fish aquarium because its value steadily declines due to the nitrification process, which increases $\mathrm{H}^{+}$and $\mathrm{NO}_{3}{ }^{-}$ions in the aquarium. An essential item in the fish aquarium is a $\mathrm{pH}$ stabilizer because this variable is critical to all the living organisms (fish, plants, and bacteria) in the aquarium. The recommended $\mathrm{pH}$ range for freshwater fish is 6.8 to 7.2 [24,28]. Timmons et al. [31] reported a thriving fish culture in the range of 6.5-8.5. Fantail goldfish was successfully reared in this study when the $\mathrm{pH}$ range was $7.81 \pm 0.39$ to $7.89 \pm 0.46$. The impact of duckweed growth on water quality in sub-tropical pond sediment has been reported to be significant at $\mathrm{pH}$ values 6.9 and 9.1 [32]. The $\mathrm{pH}$ values in ponds with aquatic plants are generally slightly alkaline in the range of 7-8 [18]. Latha and Lipton [28] have reported that lower $\mathrm{pH}$ can enhance the formation of ammonia in the water, affect the functions of the fish gills, and prove detrimental to the growth of denitrifying bacteria. On the other hand, a $\mathrm{pH}$ of less than 7 can slow down the nitrification process, and if the decline in $\mathrm{pH}$ reaches less than 5 , the nitrification process can stop. This level of acidity exerts strong stress on the fish and can threaten its survival [31].

\subsection{Ex situ Water Quality}

The mean \pm SD concentrations of TSS, $\mathrm{NH}_{3}{ }^{-}-\mathrm{N}, \mathrm{NO}_{2}-\mathrm{N}, \mathrm{NO}_{3}-\mathrm{N}$, and $\mathrm{PO}_{4}-\mathrm{P}$ in three different aquariums are shown in Table 1. Analysis of variance (ANOVA) revealed that the concentrations of TSS, $\mathrm{NH}_{3}{ }^{-}-\mathrm{N}, \mathrm{NO}_{3}-\mathrm{N}$, and $\mathrm{PO}_{4}-\mathrm{P}$ in three aquariums were significantly different $(p<0.05)$, but there was no appreciable difference $(p>0.05)$ in the $\mathrm{NO}_{2}-\mathrm{N}$ concentration. Figure 4 presents data on changes in TSS, $\mathrm{NH}_{3}-\mathrm{N}, \mathrm{NO}_{3}-\mathrm{N}$, and $\mathrm{PO}_{4}-$ 
P concentrations from day 1 (week 0 ) until week 7. Evidently, the highest TSS concentration recorded was $41.03 \pm 37.1 \mathrm{mg} / \mathrm{L}$ in the control aquarium, followed by $26.27 \pm 13.41 \mathrm{mg} / \mathrm{L}$ in the duckweed aquarium and the lowest $(23.02 \pm 8.90 \mathrm{mg} / \mathrm{L})$ in the azolla aquarium. The $\mathrm{NH}_{3}-\mathrm{N}$ concentration was lowest in the azolla aquarium, $0.06 \pm 0.04 \mathrm{mg} / \mathrm{L}$, followed by $0.09 \pm 0.07 \mathrm{mg} / \mathrm{L}$ in the duckweed aquarium and $0.10 \pm 0.08 \mathrm{mg} / \mathrm{L}$ in the control aquarium.

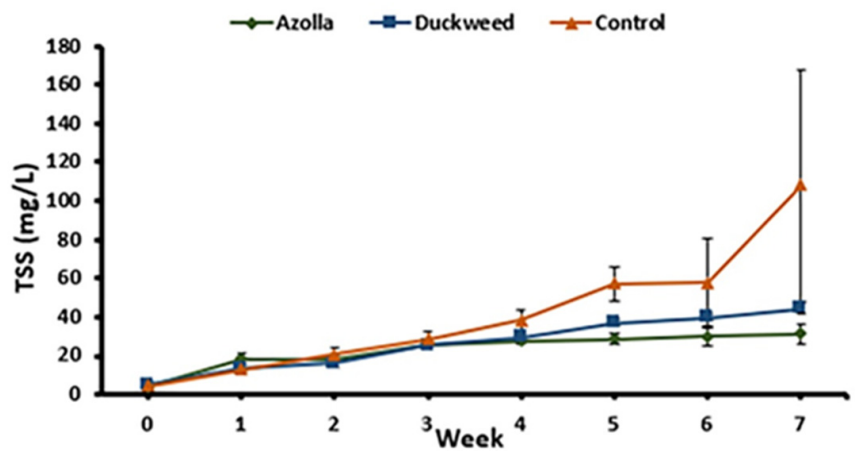

(a)

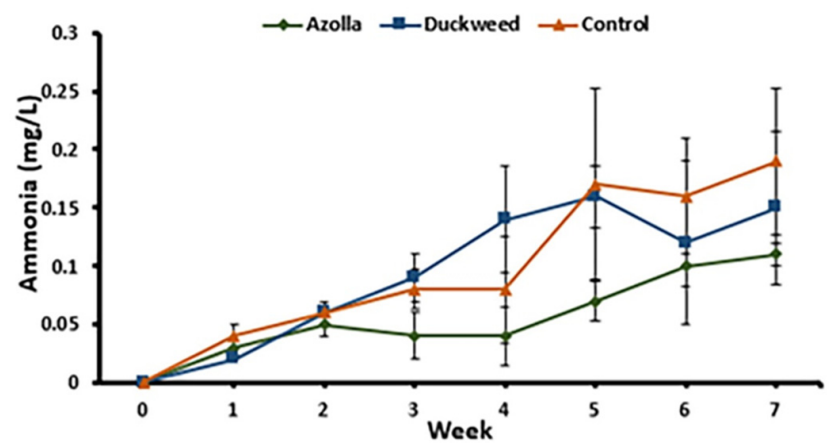

(b)

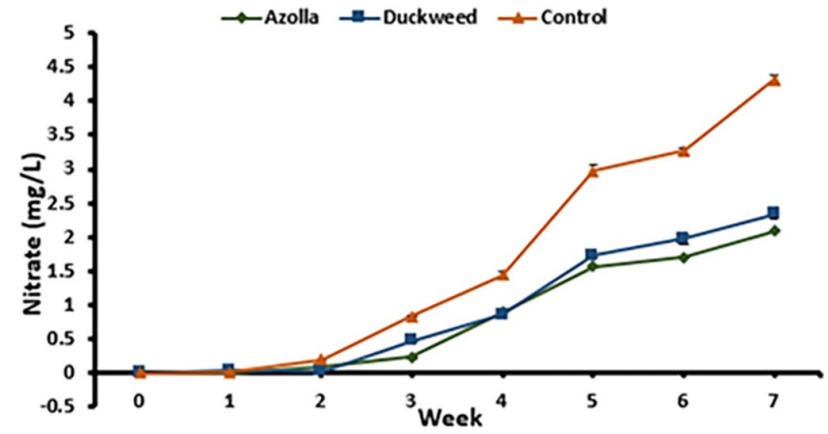

(c)

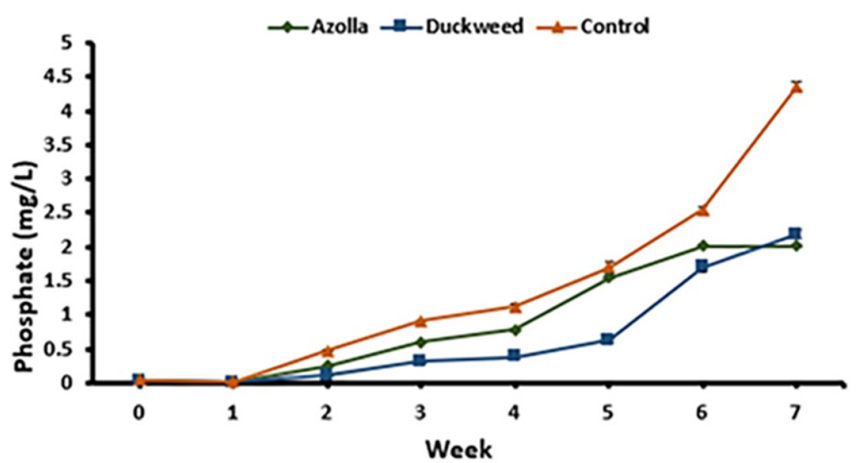

(d)

Figure 4. Means + SDs of (a) Total Suspended Solids (TSS), (b) ammonia, (c) nitrate, and (d) phosphate concentrations in the three different aquariums (azolla, duckweed, and control) during the 49 days experiment. 
Concentrations of $\mathrm{NO}_{3}-\mathrm{N}$ and $\mathrm{PO}_{4}-\mathrm{P}$ were higher in the control aquarium, amounting to $1.37-1.51 \mathrm{mg} / \mathrm{L}$ and $1.40-1.49 \mathrm{mg} / \mathrm{L}$, respectively, followed by the azolla aquarium with concentrations of $0.83-0.84 \mathrm{mg} / \mathrm{L}$ and $0.93-0.97 \mathrm{mg} / \mathrm{L}$, respectively. The lowest value was observed in the duckweed aquarium, $0.91-0.92 \mathrm{mg} / \mathrm{L}$ and $0.72-0.92 \mathrm{mg} / \mathrm{L}$, respectively. Our results showed that TSS, $\mathrm{NH}_{3}, \mathrm{NO}_{2}$, and $\mathrm{PO}_{4}$ concentrations were significantly different $(p<0.05)$ among the three treatments. The lowest TSS concentration was recorded in the azolla aquarium, followed by the duckweed aquarium, and then the control. Data from the azolla and duckweed aquariums indicated that biological processes tend to reduce TSS and enhance water quality (Table 1). TSS in the control aquarium is significantly higher during week 7, which was more than $100 \mathrm{mg} / \mathrm{L}$. Suspended solids in the water may occur in inorganic, organic or mixed organic, and inorganic forms $[8,24]$. The natural sources of suspended solids are silt and detritus generated by bioactivity, chemical reactions, and sediment resuspension due to current and wave action and possibly some quantities originating from the air. The concentration of suspended solids in the range of 100-100,000 mg/L can be lethal, but values of 10-100 mg/L are typically sublethal [33]. The common sublethal responses to suspended solids account for increases in haemoglobin and red blood cell count and hematocrit values [34]. Higher TSS concentrations develop cloudy conditions in the water due to accumulation of solid particles, dissolved organic matter, and algae. The reduction in suspended faecal matter in the water can result in an imbalance in the bacterial population and increase the concentration of toxic compounds such as $\mathrm{NH}_{3}$ and $\mathrm{NO}_{2}$, affecting fish health [35]. Estim et al. [8] have highlighted that the suspended solids harm the fish directly by clogging the gill structures. The stress imposed on the fish suppresses their immune system, increases the vulnerability to diseases, and impairs osmoregulation [36]. Mass mortality of fish where decay of a large biomass of organic matter takes place is mainly attributed to a decline in DO availability [37].

Ammonia is a significant problem in the aquarium due to its toxicity with respect to fish. Ammonia toxicity manifests in multiple ways, such as disturbed salt-water balance, kidney failure, branchial dysfunction, neurological impairment, and cytological damage. This diminishes the ability of the fish to eliminate endogenous ammonia [38]. The total ammonia in the water occurs in an ionized form (ammonium) and un-ionized state. The results generated through ANOVAs showed that the highest $\mathrm{NH}_{3}$ concentration was in the control aquarium, followed by the duckweed aquarium. The azolla aquarium produced the best result in reducing ammonia concentration. The toxic level of ammonia in short-term exposure was usually in the range of 0.6 to $2.0 \mathrm{mg} / \mathrm{L}$, while the maximum tolerable level was $0.1 \mathrm{mg} / \mathrm{L}[8,24,28]$. Ammonia effects on the fish depend on its concentration and species tolerance. Some species are more susceptible even when the exposure period is short $[8,10]$. Un-ionized ammonia has been observed to be harmful with respect to culture of several species even at $0.05 \mathrm{mg} / \mathrm{L}$, causing growth retardation, reduced fecundity and fertility, severe stress, and vulnerability to pathogens [24].

In response to ammonia poisoning, the gills become red, skin color darkens, and fish starts gasping at the surface. Toxic levels can be reached in a relatively short period of time and cause death. In some fish species, the gills are damaged when the concentration is as low as $0.25 \mathrm{mg} / \mathrm{L}$ [9]. Mortality occurs rapidly at concentrations exceeding $2.0 \mathrm{mg} / \mathrm{L}$.

There is a paucity of data on chronic nitrate toxicity at various stages of fish in a culture system. In this study, the lowest nitrate concentration was recorded in the azolla aquarium, followed by the duckweed aquarium. The control aquarium showed the highest value $(1.6 \mathrm{mg} / \mathrm{L})$, and this is a nontoxic level. Concentration over $300 \mathrm{mg} / \mathrm{L}$ can be a cause for concern [39]. Azolla and duckweed in the aquarium used $\mathrm{NO}_{3}$ for nourishment, which reduced its concentration compared to the control aquarium. Recirculating aquaculture systems operate with very low water exchange, and higher $\mathrm{NO}_{3}$ concentration can cause toxicity to fish [40]. The $\mathrm{NO}_{3}$ levels (80 to $100 \mathrm{mg} / \mathrm{L}$ ) for extended periods are associated with stress in the juvenile rainbow trout reared in recirculating systems. The impaired conditions of the fish were evident from changes in swimming behaviour, reduced survival, and decreased total biomass. However, in aquaponics or other integrated cultures with 
plants, the nitrogen compounds should always be evaluated together with a general health check on the fish due to the modulation of the nitrogen cycle [41]. The removal of nutrients is considerably influenced by the plant species.

Some fish species are very susceptible to $\mathrm{NO}_{2}$ and suffer from stress even at small periods of exposure [42]. The problems related to $\mathrm{NO}_{2}$ typically occur in closed aquaculture systems due to an inefficient and inadequate process of removal of $\mathrm{NH}_{3}$ through biofiltration [43]. Nitrite concentration in blood plasma can accumulate up to ten times higher than the concentration in the surrounding water [44]. According to Cameron [45], the transport of oxygen in the fish blood is constrained by oxidation of haemoglobin $(\mathrm{Hb})$ to methemoglobin $(\mathrm{metHb})$ under prevailing $\mathrm{NO}_{2}$ toxicity. MetHb reduces the oxygen distribution to the tissues [43]. Yildiz et al. [42] reported that $\mathrm{NO}_{3}$ exposure in the range of $0.50-1.38 \mathrm{mg} / \mathrm{L}$ for $48 \mathrm{~h}$ caused a decrease in $\mathrm{Hb}$ and hematocrit and increased $\mathrm{MetHb}$ levels in fish blood. Over $50 \%$ of the metHb concentration was fatal for the fish [46].

Nitrification is a microbial process that reduces nitrogen compounds (especially $\mathrm{NH}_{3}$ ), sequentially oxidizing them to $\mathrm{NO}_{2}$ and $\mathrm{NO}_{3}$. Ammonia is generated in aquarium water through fish waste and uneaten feed. The nitrification process is carried out by autotrophic nitrifying bacteria that can build organic molecules using inorganic sources. Present results showed that $\mathrm{PO}_{4}$ concentration in the duckweed aquarium was the lowest of all the sets, followed by the concentration in the azolla aquarium. The highest value was in the control aquarium. Obviously, uptake by azolla and duckweed made a significant difference in the phosphate profile. Duckweed was more efficient compared to azolla and control treatments in terms of phosphate uptake. Landolt and Kandeler [47] reported that azolla requires a high level of phosphorus for growth. This nutrient can become a major limiting factor after nitrogen. Phosphate naturally increases with the decomposition of the waste in the aquarium. In addition to being produced internally, $\mathrm{PO}_{4}$ is also able to enter the aquarium system through external sources and not only from the food provided but also from the water source used, especially the chemicals used for buffering tap water [24,47].

\subsection{Growth Performance of Fantail Goldfish}

Table 2 presents data on the growth performance, SGR, survival, feed intake, and FCR of fantail goldfish in the three aquariums during the 7-week trial. Statistical analysis showed that the final weight and length and SGR of fantail goldfish in the three aquariums were significantly different $(p<0.05)$, while no significant differences $(p>0.05)$ were observed in weight and length gain, survival rate, feed intake, and FCR. The highest final weight, final length, and SGR were recorded in the duckweed aquarium, followed by the azolla aquarium and the control aquarium (Table 2). The range of values of initial weight and initial length were $2.24 \pm 0.21 \mathrm{~g}$ to $2.39 \pm 0.17 \mathrm{~g}$ and $5.05 \pm 0.11 \mathrm{~g}$ to $5.20 \pm 0.08 \mathrm{~g}$, respectively. The feed intake and FCR were $72.2 \pm 6.2 \mathrm{~g}-132.1 \pm 6.6 \mathrm{~g}$ and $1.07 \pm 0.28-1.17 \pm 0.58$, respectively. The survival rate was $100 \%$ in all treatments.

Similarly, to other aquatic plants, duckweed also needs many trace elements such as nitrogen, phosphorous, and potassium [48]. Duckweed possesses well-developed mechanisms for uptake and utilization of these substances. Duckweed can tolerate high concentrations of macronutrients as well as micronutrients and possesses efficient mineral absorption capacity [13]. Ferdoushi et al. [18] conducted investigations using duckweed as a biofilter in an aquaculture system receiving effluents from fish farms and demonstrated the plant's water remediation capacity. It is essential to recognize that a sustainable aquarium system needs to balance nutrient levels for optimal growth of fish and nitrifying bacteria.

The final weight, final length, and SGR of fantail goldfish in the three aquariums were significantly different after seven weeks of trial. There was no mortality, and the duckweed aquarium showed the highest value, followed by the azolla and the control aquariums. All fish specimens showed positive signs of growth and normal behaviour expected of healthy specimens. The duckweed aquarium with commercial feed for the fantail goldfish promoted better feed efficiency compared to the other aquariums. Galkina et al. [49] have also noticed faster growth of grass carp when integrated with duckweed than compared 
to the other feed materials. Common carp, catfish, and tilapia were the most active users of fresh duckweed [50]. According to Fasakin et al. [51] duckweed can contribute up to 30 percent of the total feed without significantly affecting growth performance. Evidence presented suggested that duckweed could be efficiently assimilated into the biomass of tilapia and carp [50,52].

Table 2. Initial and final weight, initial and final length, weight gain, length gain, SGR, survival, feed intake, and FCR of the fantail goldfish in the three different treatment aquariums.

\begin{tabular}{cccc}
\hline Parameter & \multicolumn{3}{c}{ Treatment } \\
\hline tREA & Azolla & Duckweed & Control \\
\hline Initial weight $(\mathrm{g})$ & $2.39 \pm 0.17^{\mathrm{a}}$ & $2.27 \pm 0.27^{\mathrm{a}}$ & $2.24 \pm 0.21^{\mathrm{a}}$ \\
Final weight $(\mathrm{g})$ & $4.79 \pm 0.10^{\mathrm{b}}$ & $5.18 \pm 0.14^{\mathrm{c}}$ & $3.69 \pm 0.23^{\mathrm{a}}$ \\
Initial length $(\mathrm{cm})$ & $5.05 \pm 0.11^{\mathrm{a}}$ & $5.20 \pm 0.08^{\mathrm{a}}$ & $5.16 \pm 0.09^{\mathrm{a}}$ \\
Final length $(\mathrm{cm})$ & $6.32 \pm 0.11^{\mathrm{a}}$ & $6.57 \pm 0.13^{\mathrm{b}}$ & $6.15 \pm 0.10^{\mathrm{a}}$ \\
Weight gain $(\%)$ & $106.07 \pm 27.92^{\mathrm{a}}$ & $130.22 \pm 37.58^{\mathrm{a}}$ & $71.93 \pm 31.64^{\mathrm{a}}$ \\
Length gain (\%) & $24.99 \pm 2.26^{\mathrm{a}}$ & $27.26 \pm 9.95^{\mathrm{a}}$ & $19.708 \pm 8.18^{\mathrm{a}}$ \\
SGR (\%/day) & $5.10 \pm 0.90^{\mathrm{ab}}$ & $5.93 \pm 1.07^{\mathrm{b}}$ & $3.20 \pm 1.23^{\mathrm{a}}$ \\
Survival (\%) & $100.00 \pm 0.00^{\mathrm{a}}$ & $100.00 \pm 0.00^{\mathrm{a}}$ & $100.00 \pm 0.00^{\mathrm{a}}$ \\
Feed intake (g) & $111.80 \pm 2.44^{\mathrm{a}}$ & $132.12 \pm 6.55^{\mathrm{a}}$ & $72.18 \pm 6.21^{\mathrm{a}}$ \\
FCR & $1.09 \pm 0.233^{\mathrm{a}}$ & $1.07 \pm 0.28^{\mathrm{a}}$ & $1.17 \pm 0.58^{\mathrm{a}}$ \\
\hline
\end{tabular}

Note: Values are expressed as mean + standard deviation, $n=24$. Different superscript letters ${ }^{a, b, c}$ within a column indicate significant differences between treatment sets at the level of $p<0.05$.

Supplements in fantail goldfish diets could include cacao bean meals for better growth and reproduction performance, economic efficiency, and health of the rearing system [53]. Adding cacao bean meal to the diets of fantail goldfish can also improve the feeding cost. The most expensive product in fish production is feed, accounting for around $45 \%$ of the total cost [53]. Many efforts have been made to identify pathways to reduce feed costs in assessing the dietary supplement for fish production [54]. Products extracted from Aspilia mossambicensis and Azadirachta indica leaf have been tested [55]. Extracts of Carica papaya as a dietary supplement could enhance gonadal development and improve growth [56]. Duckweed and azolla are also suitable for fish feed because of their protein, vitamins, and minerals contents $[11,19]$. Both aquatic plants are easily accommodated in limited spaces due to small leaves that float at the surface and are a source of nourishment for the stocked fish $[14-17,19]$.

\section{Conclusions}

This study demonstrated that the aquatic plants such as the duckweed and azolla which are considered invasive weeds can play an important role in biofiltration and water quality remediation in aquarium stocked with the fantail goldfish. These two plants also serve as additional feed ingredients for the fish. It is a sort of biological pruning of the plants. The experimental results revealed that the feed efficiency was better with the duckweed compared to azolla. The duckweed supported better growth performance of the fantail goldfish. The combination of fish and aquatic plants in an aquaculture system is cost-effective, resource-efficient, and environment-friendly. More follow-up studies should be conducted involving different species of ornamental fish and plants to support the aquarium trade.

Author Contributions: Conceptualization, A.E.; methodology, A.E. and M.N.A.M.R.; validation, A.E., S.M. and B.A.V.M.; formal analysis, M.N.A.M.R. and A.E.; writing-original draft preparation, M.N.A.M.R. and A.E.; writing—review and editing, A.E., S.M. and B.A.V.M.; supervision, A.E. and S.M.; funding acquisition, A.E. All authors have read and agreed to the published version of the manuscript.

Funding: Project funded by the Ministry of Higher Education of Malaysia (NRGS 0001) to A.E. 
Institutional Review Board Statement: Not applicable.

Informed Consent Statement: Not applicable.

Data Availability Statement: Not applicable.

Conflicts of Interest: The authors declare no conflict of interest.

\section{References}

1. $\mathrm{Ng}, \mathrm{C}$. The ornamental fish trade in Malaysia. UTAR Agric. Sci. J. 2016, 2, 4.

2. Safer, M. Aquatic Invaders of the Pacific Northwest: Carassius auratus (Common Goldfish); Washington Department of Fish and Wildlife Fish: Olympia, WA, USA, 2014; p. 423.

3. Lim, L.C.; Wong, C.C. Use of the rotifer, Brachionus calyciflorus Pallas, in freshwater ornamental fish larviculture. Hydrobiologia 1997, 358, 269-273. [CrossRef]

4. DOF (Department of Fisheries Malaysia). List of Registered Ornamental Fish Exporters. 2018. Available online: http://www.dof. gov.my/dof2/resources/user_1/UploadFile/Biosekuriti\%20.Revision (accessed on 12 June 2021).

5. Lorenzoni, M.; Corboli, M.; Ghetti, L.; Giovanni, P.; Carosi, A. Growth and reproduction of the goldfish Carassius auratus: A case study from Italy. In Biological Invaders in Inland Waters: Profiles, Distribution, and Threats; Invading Nature-Springer Series Invasion Ecology; Gherardi, F., Ed.; Springer: Dordrecht, The Netherlands, 2007; Volume 2. [CrossRef]

6. Ota, K.G.; Abe, G. Gold fish morphology as a model for evolutionary developmental biology. WIREs Dev. Biol. 2016, 5, $272-295$. [CrossRef] [PubMed]

7. Andrews, C. Guide to Fancy Goldfish, Fishkeeper's Guides; Interpet Publishing: Dorking, UK, 2002.

8. Estim, A.; Saufie, S.; Mustafa, S. Water quality remediation using aquaponics sub-systems as biological and mechanical filters in aquaculture. J. Water Process Eng. 2019, 30, 100566. [CrossRef]

9. Datta, S. Aquarium Water Quality Management; FISHCOOPS Edition: XXVI (III); National Federation of Fishers Cooperative Ltd.: New Delhi, India, 2012; pp. 9-16.

10. Estim, A. Water Quality Management in a Marine Fish Hatchery System. Ph.D. Dissertation, Universiti Malaysia Sabah, Kota Kinabalu, Malaysia, 2010.

11. Kabir, A.N.; Hossain, M.A.; Rahman, M.S. Use of Duckweed as Feed for Fishes in Polyculture. J. Agric. Rural Dev. 2009, 7, 157-160. [CrossRef]

12. Ford, T.; Beitinger, T.L. Temperature tolerance in the goldfish, Carassius auratus. J. Ther. Biol. 2005, 30, 147-152. [CrossRef]

13. Hasan, M.R.; Chakrabarti, R. Use of Algae and Aquatic Macrophytes as Feed in Small-Scale Aquaculture; FAO Fisheries and Aquaculture Technical Paper 531; Food and Agriculture Organization of the United Nations: Rome, Italy, 2009.

14. Landolt, E. Biosystematic Investigations in the Family of Duckweeds (Lemnaceae), Vol. 2. The Family of Lemnaceae-A Monographic Study, Vol. 1; Veroffentlichungen des Geobotanischen Institutes der E. T. H., Stiftung Rubel: Zurich, Switzerland, $1986 ;$ p. 638.

15. Leng, R.A.; Stambolie, J.H.; Bell, R. Duckweed-A Potential High-Protein Feed Resource for Domestic Animals and Fish; Centre for Duckweed Research and Development University of New England: Armidale, NSW, Australia, 1995; p. 7.

16. Small, E.; Darbyshire, S.J. Blossoming treasures of Biodiversity: 35. Mosquito ferns (Azolla species)—Tiny 'super plants'. Biodiversity 2011, 12, 119-128. [CrossRef]

17. Cagauan, A.G.; Pullin, R.S.V. Azolla in aquaculture: Past, present and future. In Recent Advances in Aquaculture; Muir, J., Roberts, R.J., Eds.; Blackwell Science: Oxford, UK, 1994; pp. 104-130.

18. Ferdoushi, Z.; Haque, F.; Khan, S.; Haque, M. The effects of two aquatic floating macrophytes (Lemna and Azolla) as biofilters of Nitrogen and Phosphate in fish ponds. Turkish J. Fish. Aquat. Sci. 2008, 8, 253-258.

19. Das, M.; Rahim, F.I.; Hossain, M.A. Evaluation of fresh Azolla pinata as a low-cost supplemental feed for Thai silver barb Barbonymus gonionotus. Fishes 2018, 3, 15. [CrossRef]

20. Liu, X.; Min, C.; Xia-shi, L.; Chungchu, L. Research on some functions of Azolla in CELSS system. Acta Astronaut. 2008, 63, 1061-1066. [CrossRef]

21. Hafeez-ur-Rehman, M.; Iqbal, K.J.; Abbas, F.; Mushtaq, F.M.; Rasool, F.; Parveen, S. Influence of feeding frequency on growth performance and body indices of goldfish (Carassius auratus). J. Aquat. Res. Dev. 2015, 6, 1000336. [CrossRef]

22. Appenroth, K.-J.; Sree, K.S.; Bohm, V.; Hammann, S.; Vetter, W.; Leiterer, M.; Jahreis, G. Nutritional value of duckweeds (Lemnaceae) as human food. Food Chem. 2017, 217, 266-273.

23. Wetzel, R.G.; Likens, G.E. Limnological Analyses, 2nd ed.; Springer: New York, NY, USA, 1991.

24. Boyd, C.E.; Tucker, C.S. Pond Aquaculture Water Quality Management; Kluwer Academic Publishers: Boston, MA, USA, 1998.

25. Colt, J.E.; Tamasso, J.R. Hatchery water supply and treatment. In Fish Hatchery Management, 2nd ed.; American Fisheries Society: Bethesda, MD, USA, 2012.

26. Jones, D.R. The effect of hypoxia and anaemia on the swimming performance of rainbow trout (Salmo gairdneri). J. Exp. Biol. 1971, 55, 541-551. [CrossRef] [PubMed]

27. Nico, L.G.; Schofield, P.J.; Larson, J.; Makled, T.H.; Fusaro, A. Carassius auratus. USGS Nonindigenous Aquatic Species Database, Gainesville: 2014. Available online: https:/ / nas.er.usgs.gov/queries/factsheet.aspx?SpeciesID=508 (accessed on 30 June 2021).

28. Latha, Y.P.; Lipton, A.P. Water quality management in gold fish (Carassius auratus) rearing tanks using different filter materials. Ind. Hydrobiol. 2007, 10, 301302. 
29. Skillicorn, P.; Spira, W.; Journey, W. Duckweed Aquaculture: A New Aquatic Farming System for Developing Countries; The World Bank: Washington, DC, USA, 1993; p. 76.

30. Hove, C.V. Azolla and Its Multipurpose Uses with Emphasis on Africa; FAO: Rome, Italy, 1989; p. 53.

31. Timmons, M.B.; Ebeling, J.M.; Wheaton, F.W.; Summerfelt, S.T.; Vinci, B.J. Recirculating Aquaculture Systems, 2nd ed.; Cayuga Aqua Ventures: New York, NY, USA, 2002.

32. Sengupta, S.; Medda, C.; Dewanji, A. The impact of duckweed growth on water quality in sub-tropical ponds. Environmentalist 2010, 30, 353-360. [CrossRef]

33. Lake, R.G.; Hinch, S.G. Acute effects of suspended sediment angularity on juvenile coho salmon (Oncorhynchus kisutch). Can. J. Fish. Aquat. Sci. 1999, 56, 862-867. [CrossRef]

34. Wilber, D.H.; Clarke, D.G. Biological effects of suspended sediments: A review of suspended sediment impacts on fish and shellfish with relation to dredging activities in estuaries. N. Am. J. Fish. Manag. 2001, 21, 855-858. [CrossRef]

35. Bilotta, G.S.; Brazier, R.E. Understanding the influence of suspended solids on water quality and aquatic biota. Water Res. 2008, 42, 2849-2861. [CrossRef]

36. Redding, J.M.; Schreck, C.B.; Everest, F.H. Physiological effects on Coho Salmon and steelhead of exposure to suspended solids. Tran. Amer. Fish. Soc. 1987, 116, 737-744. [CrossRef]

37. Welch, E.B.; Lindell, T. Ecological effects of wastewater. In Applied Limnology and Pollution Effects; E \& FN Spon: New York, NY, USA, 1992; p. 425.

38. Meade, J.W. Allowable ammonia for fish culture. Prog. Fish.-Cult. 1985, 47, 135-145. [CrossRef]

39. Masser, M.P.; James Rakocy, J.; Thomas, M.; Losordo, T.M. Recirculating Aquaculture Tank Production Systems: An Overview of Critical Considerations; SRAC Publication No. 452; SRAC Publication: Stoneville, MS, USA, 1999.

40. Davidson, J.; Good, C.; Welsh, C.; Summerfelt, T. Comparing the effects of high vs. low nitrate on the health, performance, and welfare of juvenile rainbow trout Oncorhynchus mykiss within water recirculating aquaculture systems. Aquac. Eng. 2014, 59, 30-40. [CrossRef]

41. Buzby, K.; Lin, L.S. Scaling aquaponic systems: Balancing plant uptake with fish output. Aquac. Eng. 2014, 63, 39-44. [CrossRef]

42. Yildiz, H.Y.; Robaina, L.; Pirhonen, J.; Mente, E.; Dominguez, D.; Parisi, G. Fish welfare in aquaponic system: Its relation to water quality with an emphasis on feed and feces-a review. Water 2017, 9, 13. [CrossRef]

43. Kroupova, H.; Máchová, J.; Svobodová, Z.; Piačková, V.; Smutná, M. The ability of recovery in common carp after nitrite poisoning. Vet. Med.-Czech. 2006, 51, 423-431. [CrossRef]

44. Eddy, F.B.; Kunzlik, P.A.; Bath, R.N. Uptake and loss of nitrite from the blood of rainbow trout, Salmo gairdneri Richardson, and Atlantic salmon, Salmo salar L., in fresh water and in dilute seawater. J. Fish. Biol 1983, 23, 105-116. [CrossRef]

45. Cameron, J.N. Methaemoglobin in erythrocytes of rainbow trout. Comp. Biochem. Physiol. 1971, 40, 743-749. [CrossRef]

46. Bowser, P.R.; Falls, W.W.; VanZandt, J.; Collier, N.; Phillips, J.D. Methemoglobinemia in channel catfish: Methods of prevention. Prog. Fish.-Cult. 1983, 45, 154-158. [CrossRef]

47. Landolt, E.; Kandeler, R. The Family of Lemnaceaea Monographic Study; Stiftung Ruebel: Zuerich, Switzerland, 1987 ; pp. 638-650.

48. Goopy, J.; Murray, P. A review of the role of duckweed in nutrient reclamation and as a source of animal feed. Asian-Austral. J. Anim. Sci. 2003, 16, 297-305. [CrossRef]

49. Galkina, N.V.; Abdullaev, D.A.; Zacharova, V.L. Biological and feed features of duckweeds. Uzbekistan Biol. J. $1965,3,44-47$.

50. Gaigher, I.G.; Short, R. An evaluation of duckweed (Lemnaceae) as a candidate for aquaculture in South Africa. In Aquaculture 1980 Report Series No. 15; Wamsley, R.D., Wan, J.G., Eds.; CSIRO: Canberra, Australia, 1986; Volume 15, pp. 81-90.

51. Fasakin, E.A.; Balogum, A.M.; Fasuru, B.E. Use of duckweed, Spirodela polyrrhiza L. Schleiden, as a protein feedstuff in practical diets for tilapia, Oreochromis niloticus L. Aquac. Res. 1999, 30, 313-318. [CrossRef]

52. Robinette, H.R.; Brunson, M.W.; Day, E.J. Use of duckweed in diets of channel catfish. Proc. Annu. Conf.-Southeast. Assoc. Fish Wildl. Agencies 1980, 34, 108-114.

53. Al-Khalaifah, H.S.; Amer, S.A.; Al-Sadek, D.M.M.; Khalil, A.A.; Zaki, E.M.; El-Araby, D.A. Optimizing the Growth, Health, Reproductive Performance, and Gonadal Histology of Broodstock Fantail Goldfish (Carassius auratus) by Dietary Cacao Bean Meal. Animals 2020, 10, 1808. [CrossRef] [PubMed]

54. Amer, S.A.; Ahmed, S.A.; Ibrahim, R.E.; Al-Gabri, N.A.; Osman, A.; Sitohy, M. Impact of partial substitution of fish meal by methylated soy protein isolates on the nutritional, immunological, and health aspects of Nile tilapia, Oreochromis niloticus fingerlings. Aquaculture 2020, 518, 734871. [CrossRef]

55. Kapinga, I.B.; Limbu, S.M.; Madalla, N.A.; Kimaro, W.H.; Mabiki, F.P.; Lamtane, H.A.; Tamatamah, R.A. Dietary Aspilia mossambicensis and Azadirachta indica supplementation alter gonadal characteristics and histology of juvenile Nile tilapia (Oreochromis niloticus). Aquac. Res. 2019, 50, 573-580. [CrossRef]

56. Kareem, Z.H.; Abdelhadi, Y.M.; Christianus, A.; Karim, M.; Romano, N. Effects of some dietary crude plant extracts on the growth and gonadal maturity of Nile tilapia (Oreochromis niloticus) and their resistance to Streptococcus agalactiae infection. Fish. Physiol. Biochem. 2016, 42, 757-769. [CrossRef] [PubMed] 